UDK 262.2(497.5 Desne-Rujnica)"18" (093)

314.82(497.5 Desne-Rujnica)"18"(093)

Primljeno: 8. 2. 2017.

Prihvaćeno: 1. 6. 2017.

Izvorni znanstveni rad

DOI: $10.22586 /$ pp.v52i0.9

\title{
Prirodno kretanje stanovništva župe Desne-Rujnica u prvoj polovici 19. stoljeća
}

\author{
Maja Šunjić \\ Obala 1 br. 23 \\ 20270 Vela Luka \\ Republika Hrvatska \\ E-adresa: maja.sunjic11@gmail.com
}

U radu se analiziraju sastavnice prirodnoga kretanja stanovništva te teme vezane uz vjenčanja, porode i strukturu kućanstava u prvoj polovici 19. stoljeća sa završnim osvrtom na proces demografske tranzicije kroz usporedbu rezultata ovoga rada s dosad objavljenim analizama.

Ključne riječi: Desne, Rujnica, Neretva, vjenčanja, porodi, demografska tranzicija, 19. stoljeće

Područje nekadašnje župe Desne-Rujnica nalazi se na desnoj obali donjega toka Neretve i zauzima područje planine Rujnica, dominantnoga masiva koji se pruža u smjeru sjeverozapad-jugoistok te krajnjim jugoistočnim završetkom Bobalj pored današnjega naselja Kula Norinska dotiče rijeku Neretvu. S jugoistočne strane obronci Rujnice od Neretve su odijeljeni brdom Donja gora. Na južnoj strani nalazi se Desansko jezero s rječicom Desankom gdje danas prevladava močvaran teren koji je tek djelomično melioriran. Prema zapadu se nadovezuju brda Pline, dok je teritorij župe sa sjevera odijeljen borovačkom visoravni (Karta 1).

Župa Desne-Rujnica formirana je 1760. godine izdvajanjem iz župe Borovci, a u tome je opsegu funkcionirala do 1921 . godine. ${ }^{1}$ Broj naselja župe i njiho-

\footnotetext{
1 Mile Vidović, Povijest župa doline Neretve (Metković: Ogranak Matice hrvatske u Metkoviću, 2011), 82-83.
} 
va naseljenost stalno su se mijenjali s tendencijom napuštanja brdskih naselja i približavanja rijeci Neretvi. Matične knjige ove župe pokazuju da je ona u prvoj polovici 19. stoljeća obuhvaćala naselja Desne, Rujnicu, Bagaloviće, Podrujnicu, Vrhdesne, Momiće, Arnjake i Krvavac. Potonja dva mjesta zapravo se nalaze na obroncima Donje gore. Na njih se uz sjeveroistočne obronke Rujnice nastavljaju Momići te Podrujnica kao skupni naziv za zaselke Prusci, Kalebi, Zloići i Romići. Na južnim obroncima Rujnice u kontaktnoj zoni s Desanskim jezerom smjestilo se naselje Desne sa zaselcima Marovine, Masline, Kod Crkve, Kod Kuća, Vrijaci, Strimen, Šišin i Kraj (Medaci). Toponim Desna poznat je iz srednjega vijeka. U drugoj polovici 14. stoljeća u više navrata spominje se utvrda Desna i vojna posada pod zapovjedništvom Filipa Nosdronje. ${ }^{2}$ Naselje Rujnica nalazi se na zaravni na 344 metara nadmorske visine na samoj planini Rujnica, kojoj se prilazi prijevojem između vrhova Velika Rujnica i Varda. Bagalovići se nalaze na uzvišenju od 70 metara nadmorske visine smještenome nešto zapadnije od uzvišenja Bobalj. U 17. i 18. stoljeću spominje se kao Kameno Brdo, ${ }^{3}$ a najranije u matičnoj knjizi Franjevačkoga samostana u Zaostrogu SK 198 gdje je dana 13. studenoga 1664. upisano krštenje Martina sina Mihača Bagalovića iz Kamenoga Brda. ${ }^{4}$ Prema istome prezimenu naselje se krajem 18 . stoljeća počinje nazivati Bagalović(i). ${ }^{5}$ Selo Momić dobilo je ime prema istoimenome rodu koji se također 1664. godine spominje u zaostroškoj matičnoj knjizi SK 198.

U radu se analizira prirodno kretanja stanovništva (natalitet, nupcijalitet i mortalitet) uz niz drugih pokazatelja vezanih uz vjenčanja i porode te život u zajedničkome kućanstvu (analiza strukture kućanstava). Temelji se na statističkoj i genealoškoj analizi podataka dobivenih iz matičnih knjiga župe Desne-Rujnica i stanja duša. Osnovni materijal za istraživanje su: Matična knjiga rođenih 1825. - 1830., Matična knjiga rođenih 1830. - 1851., Matična knjiga vjenčanih 1825. - 1831., Matična knjiga vjenčanih 1831. - 1857. i Matična knjiga umrlih 1825. 1861. ${ }^{6}$ Matična knjiga umrlih uglavnom je već obrađena analizom uzroka smrti i dobno-spolne strukture te objavljena u radu M. Šunjić "Na dugo pišem jerbo ne mogu se u manje iskazat: uzroci smrti u župi Desne-Rujnica (1825 - 1861)", Anali Zavoda za povijesne znanosti u Dubrovniku 51 (2013), br. 2: 461-499. Poda-

\footnotetext{
2 Radovan Jerković, Gabela (Prilog povijesti Donje Neretve) (Sarajevo: „Napredak“ - Hrvatski narodni kalendar, 1939), 5, 6, n. 12; Đurđica Petrović, Dubrovačko oružje u XIV. veku. knj. 5 (Beograd: Posebna izdanja / Vojni muzej u Beogradu, 1976), 141.

3 Vidović, Povijest župa doline Neretve, 63-64.

${ }^{4}$ Prijepis matične knjige Codex Baptismorum Descriptoru' Post Ordinationem Concilii Tridentini oznake SK 198 iz Arhiva Franjevačkog samostana u Zaostrogu. Prijepis pripremio: Žarko Despot.

5 Vidović, Povijest župa doline Neretve, 63-64.

6 Hrvatska (dalje HR) - Državni arhiv u Zadru (dalje DAZd), Zbirka matičnih knjiga, Matična knjiga rođenih 1825-1830 (dalje MKR 1825-1830) inv.br. 169, Matična knjiga rođenih 1830-1851(dalje MKR 1830-1851) inv. br. 170, Matična knjiga vjenčanih (dalje MKV 1825-1831) inv. br. 171, Matična knjiga vjenčanih 1831-1857 (dalje MKV 1831-1857) inv. br. 172 i Matična knjiga umrlih 1825-1861 (dalje MKU 1825-1861) inv. br. 173.
} 
ci koji se odnosi na izračun stope mortaliteta u ovome radu crpljeni su direktno iz izvora (matice umrlih). Drugi relevantni izvor u analizi je Status animarum župe Desne-Rujnica iz 1802. godine (M 113, bez paginacije) iz Nadbiskupskoga arhiva u Splitu. Tu su kućanstva detaljno popisana po naseljima Rujnica, Desne, Bagalovići i Momići. U procesu restitucije korišten je i Status animarum sela Vid, Borovci i Rujnica iz 1744. godine također iz Nadbiskupskoga arhiva u Splitu (M 67, ff. 380-382, dio koji se odnosi na Rujnicu f. 382). Sva navedena stanja duša već su objavljena u knjizi Mile Vidovića Povijest župa doline Neretve, Metković, 2011., ali uglavnom ne u integralnome obliku. No, uporaba ove knjige bila je od velike pomoći u radu i praćenju izvora. Osim navedenih izvora u istraživanju je korištena i druga relevantna literatura, ponajprije ona u kojoj se obrađuju druge neretvanske i dalmatinske župe u 19. stoljeću. Gotovo svi pokazatelji analizirani su usporedbom sa situacijom u župi Desne-Rujnica u razdoblju od 1870. do 1880. godine objavljenome u radu I. Bego-Matijević, Ž. Dugandžića i A. Akrapa "Tranzicija mortaliteta: Stanovništvo Desne na Neretvi (1870-1880)", Anali Zavoda za povijesne znanosti HAZU u Dubrovniku 47 (2009): 195-218. Treba napomenuti da se, ovisno o izvorima, analize izvršene u radu odnose na različite vremenske raspone između 1802. i 1861. godine. Situacija na samome početku stoljeća predstavljena je analizom strukture kućanstava s dobno-spolnom strukturom na temelju stanja duša 1802. godine. Dob ženidbe i udaje te svi ostali podaci koji su vezani za vjenčanja odnose se na razdoblje od 1825. do 1857. godine. Pitanja vezana za porode i djecu promatrana su u razdoblju od 1825. do 1851. godine. Kao što je već napomenuto, dobno-spolna analiza umrloga stanovništva prethodno je obrađena i objavljena za razdoblje od 1825. do 1861. godine. Analize stopa nataliteta, moraliteta i prirodnoga prirasta odnose se na razdoblje od 1830. do 1850. godine jer je jedino u tome rasponu bilo moguće dobiti "sjecište" potrebnih vitalnih događaja unutar dvaju godišta s poznatim brojem stanovnika.

\section{Vjenčanja}

U matičnim knjigama vjenčanih ove župe registrirano je 250 brakova. U sredinama poput onih u župi Desne-Rujnica vjenčanje se na početku 19. stoljeća prvenstveno doživljava kao crkveni sakrament i čin koji je nužan preduvjet zajedničkoga života i stvaranja obitelji, u čemu se očituje snažan utjecaj Katoličke crkve. ${ }^{7}$ Takav slijed događaja funkcionira kod većine parova. Pojedini primjeri u ovoj župi ipak pokazuju da vjenčanje nije jedini način ostvarivanja seksualnih potreba, života u dvoje ili dobivanja potomstva, neovisno o tome je li par ili pojedinac imao takve planove ili ne. Rađanje izvanbračne (nezakonite) djece dokazuje da konzumiranje spolnih odnosa nije isključivo ograničeno na brak. Pod utjecajem

\footnotetext{
Raffaella Sarti, Živjeti u kući. Stanovanje, prehrana i odijevanje u novovijekovnoj Europi (1500.-1800.), prev. Ana Badurina (Zagreb: Ibis grafika, 2006), 21.
} 
tradicije takva se "skretanja" nastoje dovesti u red. Neke situacije nisu samo ćudoredno nego i moralno upitne - kako drugačije okarakterizirati situaciju u kojoj vjenčani muškarac u izvanbračnoj aferi s ljubavnicom dobiva dijete samo mjesec dana prije smrti dugotrajno bolesne supruge?! On će kasnije stvari "izgladiti” sklapanjem novoga braka. Većina afera u ovoj župi "ozakonila” se naknadnim sklapanjem braka neovisno o tome jesu li nezakonita djeca potomci budućega supruga ili nekoga drugog muškarca. No, za neke žene - majke nezakonite djece to nije bilo rješenje. Ne znamo je li njihovom voljom ili je to rezultat okolnosti. One su rađanjem izvanbračne djece doslovno formirale vlastitu obitelj. Nema podataka o ocu djece, a bez stanja duša ne možemo niti naslutiti u kojim su kućanstvima živjele. Analizom izvora nisu nađeni slučajevi konkubinata. Često se prakticiralo održavanje višestrukih vjenčanja. U promatranome periodu zabilježeno je čak trideset prigoda u kojima su održana dvostruka vjenčanja i šest trostrukih. $U$ dva navrata održano je i peterostruko vjenčanje. No, ta je praksa vjerojatno ovisila o župniku.

\section{Sezonske varijacije vjenčanja}

Najveći broj vjenčanja sklopljen je u studenome (26,4 \%), a slijede veljača s $20 \%$ i siječanj sa $17,6 \%$ brakova (tablica 1 , grafikon 1 ). Do znatnijega porasta vjenčanja dolazi već u rujnu, koji klimatološki zapravo predstavlja jesen. U usporedbi $s$ neretvanskim župama Rogotinom i Kominom u istome periodu te Dobranjama, Vidonjama i Slivnom u drugoj polovici 19. stoljeća - gdje se veći broj vjenčanja javlja tek u listopadu ${ }^{8}$ - pomak prema ranoj jeseni (rujnu) specifičan je za Desne. Ako promatramo slijed mjeseci od rujna do studenoga, onda je broj vjenčanja u jesenskoj sezoni (rujan - studeni: 38,8 \%) izjednačen s onima u siječnju i veljači (siječanj - veljača: $38 \%$ ). Maksimalan broj vjenčanja u studenome te podjednaka zastupljenost jesenske i zimske sezone u Desnama će se zadržati i tijekom 1870ih. ${ }^{9}$ Ako se uzme u obzir rujan, u tome periodu broj vjenčanja u jesen čak postaje naglašeniji. S maksimumom vjenčanja u studenome te izjednačenošću jesenske i zimske sezone župa Desne-Rujnica za sada predstavlja izuzetak u odnosu na druga neretvanska mjesta i župe gdje je zabilježen izrazit zimski maksimum, poput Rogotina (s čak 55,17 \%) i Komina u istomr periodu te Dobranja, Vidonja, Slivna, Baćine i Opuzena sredinom druge polovice 19. stoljeća. ${ }^{10}$

8 Žarko Dugandžić, "Stanovništvo općine Metković 1850.-1918." (doktorska disertacija, Sveučilište u Zagrebu, 2011), 114-115, 203-204, tablice 61, 62 i 63; Maja Šunjić, "Stanovništvo Rogotina na kraju 18. i u prvoj polovici 19. stoljeća na temelju matičnih knjiga i stanja duša", Anali Zavoda za povijesne znanosti HAZU u Dubrovniku 45 (2007): 362, tablica 5; Maja Šunjić, "Prirodno kretanje stanovništva Komina na kraju 18. i prvoj polovici 19. stoljeća", Anali Zavoda za povijesne znanosti HAZU u Dubrovniku 50 (2012): 367, tablical.

9 Inge Bego-Matijević et al., "Tranzicija mortaliteta: Stanovništvo Desne na Neretvi (1870-1880)", Anali Zavoda za povijesne znanosti HAZU u Dubrovniku 47 (2009): 210-211, tablica 6.

10 Šunjić, "Stanovništvo Rogotina", 362, tablica 5; Šunjić, "Prirodno kretanje stanovnišstva Komina", 367, tablica1; Dugandžić, "Stanovništvo općine Metković 1850.-1918., 114-115, 203-204, tablice 61, 62 i 63; 
U slijedu mjeseci od rujna do veljače do osjetnoga pada sklopljenih brakova dolazi tijekom prosinca $(4,8 \%)$ zbog adventa, no ne može se reći da se slavlja u potpunosti izbjegavaju, što se primjećuje i u susjednome Kominu kao i na dubrovačkome području i pojedinim dalmatinskim župama u drugoj polovici 19. stoljeća, za razliku od kontinentalne Hrvatske gdje se striktno pazi na zabrane. ${ }^{11}$ No, 70-ih godina 19. stoljeća u Desnama se broj vjenčanja sklopljen tijekom prosinca znatno smanjio (1,90 \%). ${ }^{12}$ Iako je najveći broj prosinačkih vjenčanja proslavljen početkom mjeseca, nekoliko vjenčanja sklopljeno je oko samoga Božića: 22., 27. i 28. prosinca. Na blagdan Sv. Kate 25. studenoga, koji se po pučkome vjerovanju povezuje s početkom adventa, ${ }^{13}$ u promatranome su periodu sklopljena tri braka. U razdoblju oko blagdana Sv. Kate, od 23. do 26. studenoga sklopljeno je 8,4 $\%$ svih brakova. Sam blagdan možda je bio glavna motivacija, no odabir dana vjenčanja (ponedjeljak) bio je presudan. Na primjer, u ponedjeljak 26. studenoga 1855. sklopljeno je pet brakova.

U obrascu koji je karakterističan za katoličke ruralne sredine, broj vjenčanja u Desnama ponovno drastično opada tijekom ožujka (2\%) jer se taj mjesec najčešće preklapa s korizmom kada se, sukladno preporukama Crkve, u potpunosti izbjegava sklapanje vjenčanja. Tijekom svih proljetno-ljetnih mjeseci, osobito u svibnju te srpnju i kolovozu, poljoprivredni radovi utjecali su na smanjen intenzitet vjenčanja.

\section{Izbor dana vjenčanja}

Omiljeni dan za održavanje vjenčanja u župi Desne-Rujnica bio je ponedjeljak. Čak je dvije trećine vjenčanja (73,6 \%) sklopljeno upravo na taj dan (tablica 2). Ponedjeljak je također bio omiljeni dan za vjenčanja i u susjednome Kominu $(54,45 \%) .{ }^{14}$ Broj vjenčanja tijekom ostalih dana u tjednu u Desnama bio je gotovo zanemariv, a tek nešto više vjenčanja bilo je nedjeljom (12\%). Nedjelja je zasigurno kao dan posvećen Bogu bila manje prihvatljiv izbor. Teško je s punom sigurnošću reći zbog čega je ponedjeljak bio omiljeniji od nekoga drugog dana u tjednu, npr. srijede. Vjerojatno se može isključiti apotropejska pozadina običaja, a razlog je vrlo vjerojatno praktične prirode - ponedjeljak se nastavlja na nedjelju

\footnotetext{
Žarko Dugandžić, "Demografske značajke župe Baćina od 1870. do 1880. godine”, Hum - časopis Filozofskog fakulteta Sveučilišta u Mostaru 10 (2013): 438, sl. 10; Žarko Dugandžić,"Na pragu demografske tranzicije: stanovništvo župe Opuzen (1870.-1880.)”, Mostariensia 19 (2015): 109, tablica 4.

${ }^{11}$ Nenad Vekarić, Božena Vranješ-Šoljan, "Početak demografske tranzicije u Hrvatskoj", Anali Zavoda za povijesne znanosti HAZU u Dubrovniku 47 (2009): 38-39, tablica 5; Šunjić "Prirodno kretanje stanovništva Komina", 367.

${ }_{12}$ Bego-Matijević et al., "Tranzicija mortaliteta”, 211, tablica 6.

${ }^{13}$ Dunja Rihtman-Auguštin, Knjiga o Božiću, Etnološki prikaz Božića i božićnih običaja u hrvatskoj narodnoj kulturi (Zagreb: August Cesarec; Mosta; Institut za etnologiju i folkloristiku, 1992), 24.

14 Šunjić, "Prirodno kretanje stanovništva Komina", 368-369.
} 
kao jedini "neradni" dan, što je omogućavalo dovoljno vremena za pripreme za vjenčanje. Ne uočava se nijedan dan u tjednu koji bi se posebno izbjegavao pri sklapanju brakova.

\section{Dob ženidbe i udaje}

Dob stupanja u brak poznata je kod 248 parova (tablica 3). Žene su se vjenčavale s 25,11 godina, a muškarci s 27,93 godine. No, u ovaj prosjek ulaze mladenci iz ponovljenih brakova, koji su uvijek nešto stariji, što je vidljivo i iz njihovu prosječnu dob stupanja u brak koja za žene iznosi 28,81 godinu, a za muškarce 36,25 . Ako promatramo samo prve brakove oba bračna partnera, prosječna dob smanjuje se na 24,24 godine za žene i 25,97 godina za muškarce.

I dok je prosječna dob sklapanja braka za muškarce nešto niža ili podjednaka vrijednostima u Kominu, Rogotinu, Malom i Velikom Drveniku te Vinišćima u približno istome periodu, to jest u drugoj četvrtini 19. stoljeća, ${ }^{15} \mathrm{u}$ Desnama je dob žena pri sklapanju braka, pa čak i onih koje sklapaju prvi brak, najviša u odnosu na sva ova navedena mjesta. No, situacija se za žene neće mnogo promijeniti ni nekoliko desetljeća kasnije tako da sedamdesetih godina 19. stoljeća žene i dalje ulaze u brak s 25 godina, dok će se tranzicijske promjene najviše pokazati na prosječnoj dobi ženika. ${ }^{16}$

Između 1825. i 1857. godine najveći broj žena vjenčao se u svojim dvadesetima, a nešto više u dobi između 25 i 29 godina. Prije navršene 20. godine udalo se bitno manje žena ( $8,95 \%$ žena u prvim brakovima). Muškarci rijetko ulaze u brak prije navršene 20. godine (5,47\%). Slični su rezultati dobiveni za Rogotin, dok je u susjednome Kominu ta dobna skupina kod oba spola gotovo dvostruko zastupljenija, a isto vrijedi za žensku populaciju Malog i Velog Drvenika te Vinišća između 1825. i 1850. godine. ${ }^{17}$ Udjel ove dobne skupine (do navršenih devetnaest godina) u Desnama je, osobito kod žena, neuobičajeno nizak. Posebno ako promotrimo situaciju 70-ih godina 19. stoljeća kada se udjel žena koje su sklopile brak prije navršene 20 . godine drastično povećao na $17,10 \%$, dok se udio muškaraca iste dobne skupine, sukladno očekivanjima, smanjio na $1,13 \%{ }^{18} \mathrm{U}$ razdoblju između 1825. i 1857. godine u Desnama nijedna žena nije bila mlađa od sedamnaest godina pri sklapanju braka, ali je zato najmlađi zabilježeni mladoženja imao šesnaest godina. Sklopio je brak s godinu dana starijom mladenkom. Oko 60 \% muškarca

\footnotetext{
${ }^{15}$ Mladen Andreis, "Povijesna demografija Velog Drvenika, Malog Drvenika i Vinišća do god. 1900." Radovi Zavoda za povijesne znanosti HAZU u Zadru 40 (1998): 260-261, tablica 10; Šunjić, "Stanovništvo Rogotina", 364, tablica 6; Šunjić, "Prirodno kretanje stanovništva Komina”, 370, tablica 3.

${ }^{16}$ Bego-Matijević et al., "Tranzicija mortaliteta”, 215.

${ }_{17}$ Andreis, "Povijesna demografija Velog Drvenika, Malog Drvenika i Vinišća”, 260-261, tablica 10; Šunjić, "Stanovništvo Rogotina", 364, tablica 6; Šunjić, "Prirodno kretanje stanovništva Komina", 370, tablica 3.

${ }^{18}$ Vekarić, Vranješ-Šoljan, "Početak demografske tranzicije u Hrvatskoj", 52, tablica 10.
} 
vjenčalo se u svojim dvadesetim godinama. No, za razliku od žena, čak četvrtina muškaraca ulazi u brak u tridesetima, znatno češće između 30. i 34. godine života nego kasnije. Udio muškarca koji se vjenčaju u tridesetima znatnije ne opada čak ni među onima koji sklapaju prvi brak.

Razlika u godinama među bračnim partnerima u prosjeku iznosi 2,82 godine u korist muškarca, no u brakovima koji su oboma zaručnicima prvi smanjuje se na 1,73 godine.

Kod brakova u kojima je muškarac stariji od žene, razlika u godinama znatno je veća nego u suprotnome slučaju i iznosi u prosjeku 5,62 godine. Najveća zabilježena razlika u godinama - između onih supružnika kod kojih je muškarac stariji - iznosi 28 godina, a riječ je o ponovljenome braku supružnika koji ne prebivaju u župi. Kod onih koji su prebivali u župi, najveća zabilježena razlika je 27 godina koliko je u svome trećem braku bio stariji Ivan Ujdur od 23-godišnje Matije Barbir, kojoj je to bio prvi brak. Veća razlika u godinama uglavnom je vezana uz ponovljene brakove koje sklapaju udovci sa znatno mlađim mladenkama. Kod gotovo trećine brakova žena je starija od muškarca. U tim se brakovima razlika između supružnika kreće od jedne do jedanaest godina, odnosno u prosjeku iznosi 3,37 godina. Maksimalna zabilježena razlika od jedanaest godina odnosi se na tridesetogodišnju Mandu Bebić iz Desana, koja se 1832. godine vjenčala za devetnaestogodišnjega Josipa Krstičevića iz Borovaca. Za oboje je to bio prvi brak.

\section{Trajanje braka i ponovni brakovi}

Jedini razlog za prekid braka jest smrt jednoga od supružnika. Za 122 bračna para bilo je moguće ustanoviti datum vjenčanja i smrt supružnika. Prosječno trajanje braka je 16,71 godina. Nešto više od polovice brakova okončano je smrću muškarca (59 \%). Najdugotrajniji je bio brak Stipana Kaleba i Mande Jerković, koji su se vjenčali 1812. godine i zajedno proveli gotovo 43 godine.

Od 250 brakova zabilježenih u matičnoj knjizi vjenčanih u razdoblju od 1825. do 1857. godine njih 47 je ponovnih. U ponovne brakove uglavnom ulaze udovci (42 braka), a kudikamo manje udovice (13 brakova). Osam brakova bilo je sklopljeno međusobno između udovca i udovice. Udovci koji se ponovno vjenčaju imaju u prosjeku oko 37 godina. Žene (udovice i nevjenčane djevojke) s kojima su oni ulazili u brak u prosjeku su imale 28,71 godina. Najveći broj udovaca vjenčao se $\mathrm{s}$ mlađim neudanim ženama. One su u trenutku vjenčanja ipak bile nešto starije od onih žena koje su stupale u brak s muškarcima kojima je to također bio prvi brak (26,18 prema 24,24$)$. U tek nekoliko slučajeva udovci su bili mlađi od svojih mladenki kojima je to prvi brak. Udovice koje su se ponovno vjenčavale imale su u prosjeku 34,15 godina.

Udovci su u prosjeku desetak mjeseci nakon smrti partnerice sklapali novi brak. 
U pojedinim slučajevima "požurili" su se već nakon mjesec dana. Najduži period između kraja jednoga braka i sklapanja novoga iznosio je trinaest godina, no prvi brak završio je u specifičnim okolnostima. Naime, prva žena Jure Jerkovića ubijena je nakon mjesec dana braka. Njegov brak s drugom ženom zapravo je predstavljao ozakonjenje njihove predbračne veze u kojoj je rođeno izvanbračno dijete. Dvije godine prije sklapanja braka djetetova majka "prokazala" ga je da je djetetov otac, a sam Jure Jerković to je tada negirao. No, naknadni upis iz matične knjige pokazuju da je nakon više od deset godina priznao dijete.

Udovci u novi brak najčešće dovode djecu iz prethodnoga braka. Tako su nove supruge uz muža često na skrb dobivale po četvero ili petero djece koja su uglavnom bila mlađa od deset godina. Vjerojatno su djeca dobrim dijelom motivirala udovce na brže sklapanje novoga braka.

Udovice su u novi brak ulazile nakon dosta duže pauze - u prosjeku je ona iznosila oko pet godina, a najkraći razmak od jedne godine i devet mjeseci zabilježen je prilikom ponovnoga vjenčanja Matije Ujdur. Ona je iz prethodnoga braka imala dvogodišnjega sina za kojega možemo pretpostaviti da je postao član novoga kućanstva. Udovice uglavnom u novi brak ulaze bez djece ili s maksimalno jednim djetetom. No, u nekoliko situacija primijećeno je da su i one prethodno bile u brakovima s udovcima i vjerojatno "naslijedile" njihovu djecu. Nije jasno što se dogodilo s tom djecom, no malo je vjerojatno da su se pridruživala novoj obitelji svojih maćeha.

\section{Porodi}

U razdoblju između 1825. i 1851. godine u Desnama je registrirano rođenje 740 djece. Rođeno je 388 dječaka i 352 djevojčice. Lagana prevaga u broju muške nad ženskom novorođenčadi karakteristika je svjetske, ali i populacije u Hrvatskoj u 19. stoljeću. ${ }^{19}$ Usporedba matice rođenih s opaskama o uzroku smrti rodilja (majki) u matici umrlih pokazuje da mrtvorođena djeca nisu upisivana u matičnu knjigu rođenih. Ponekad se to primjenjivalo i na djecu koja su umrla odmah po rođenju. Porode su - kao i u drugim neretvanskim mjestima - obavljale priučene primalje koje su obično bile u srodstvu s rodiljom - najčešće svekrve. U Desnama su zabilježene čak 164 različite primalje, što znači da na jednu primalju u prosjeku dolazi 4,4 živorođene i krštene djece. No, u stvarnosti se broj asistencija na porodu uglavnom kreće od jedne do devet. Nekoliko primalja imalo je jako mnogo staža i asistencija (20-35 poroda) te su sasvim sigurno pomagale znatno širemu krugu žena od onoga obiteljskog. U razdoblju od 1825. do 1851. godine zabilježeno je devet rođenja blizanaca $(2,43 \%)$. Nije zamijećena veća pojavnost blizanca u odnosu na ostatak Hrvatske kao u razdoblju od 1870. do 1880. godi-

${ }_{19}$ Jakov Gelo, Demografske promjene u Hrvatskoj: od 1780. do 1981. godine (Zagreb: Globus, 1987), 166. 
ne $(4,61 \%){ }^{20}$ Većina majki blizanaca starije su višerotkinje s prosjekom oko 34 godine. $S$ izuzetkom jedne majke koja je u trenutku poroda imala 22 godine, sve ostale starije su od trideset godina. Veća učestalost blizanaca primjetna je u rodu Vučković gdje se javlja u dvije nuklearne obitelji kroz dvije generacije.

Razmak između djetetova rođenja i krštenja u prosjeku iznosi 4,5 dana. Vrlo rijetko čekalo se duže od deset dana, a u tek dva slučaja između rođenja i krštenja prošlo je mjesec dana. Svijest o krhkome zdravlju novorođenčadi i mogućnosti njihova preživljavanja najbolje se očituje u nastojanju da se djeca čim prije krste. Krštenje koje se obavlja isti dan kada je dijete rođeno gotovo je sigurno povezano s lošim zdravstvenim stanjem novorođenčeta. Jedino izravno svjedočanstvo o izvanrednim okolnostima krštenja sačuvano je u bilješci kod upisa krštenja Lucije Romić 19. rujna 1846. gdje župnik navodi da je krštenje obavljeno, ali ne po "zakonu czerkovnom." Nije navedeno je li, kao u Kominu, ${ }^{21}$ to priručno krštenje obavila primalja ili pak sam župnik. Djevojčica je umrla isti dan i upisana je u maticu umrlih.

\section{Sezonsko kretanje začeća i rođenja}

Najveći broj začeća zabilježen je u travnju i srpnju, što znači da se najviše djece rađa u siječnju i travnju (tablica 1, grafikon 1). Ovaj izračun temelji se na datumu rođenja polazeći od pretpostavke da gestacijska dob iznosi devet mjeseci, što ne mora uvijek biti slučaj. No, analiza se može načelno smatrati pouzdanom na što, na primjer, posredno ukazuje manje začeća tijekom ožujka. Naime, pad u broju začeća tijekom korizme, a koja se najčešće poklapa s ožujkom, česta je pojava u katoličkim sredinama. ${ }^{22} \mathrm{U}$ tome se periodu ne može govoriti o potpunoj seksualnoj apstinenciji, ali svakako je vidljivo svjesno nastojanje prema uzdržavanju od spolnih odnosa zbog religijskih razloga.

Najmanji broj začeća zabilježen je u periodu od rujna do prosinca s minimumom u listopadu. Vrijeme "zastoja" u broju začeća u župi Desne-Rujnica tako se poklapa s jeseni. Period zastoja također se može jasno izdvojiti u nizu istraživanih mjesta/župa, ali obično započinje već od srpnja i najčešće završava s listopadom. ${ }^{23}$ Visoka podudarnost sa sezonom zastoja začeća u Desnama primjećuje se u Kominu i Rogotinu, a u svim ovim mjestima/župama također je primjetan malen broj začeća tijekom prosinca. ${ }^{24}$ Sedamdesetih godina 19. stoljeća u župi Desne

\footnotetext{
${ }^{20}$ Bego-Matijević et al., "Tranzicija mortaliteta”, 213.

21 Šunjić, "Prirodno kretanje stanovništva Komina”, 373.

22 Philip Benedict, “The Huguenot Population of France, 1600-1685: The Demographic Fate and Customs of a Religious Minority", Transactions of the American Philosophical Society 81(1991, reprinted 1994), 5: 91.

23 Vekarić, Vranješ-Šoljan, "Početak demografske tranzicije u Hrvatskoj”, 41.

24 Šunjić, "Stanovništvo Rogotina”, 359, tablica 3; Šunjić, “Prirodno kretanje stanovništva Komina”, 375, tablica 4 .
} 
zadržao se identičan sezonalitet smanjenoga broja začeća s time da se minimum u listopadu dodatno "produbio." ${ }^{25} \mathrm{U}$ podlozi ovoga jesenskog pada u broju začetih, između ostaloga, stoji poljoprivredni način privređivanja odnosno radovi u polju. To je vrijeme berbe grožđa i maslina, koje su se u ovoj župi tada uzgajale, za razliku od ostatka donje Neretve.

Vrlo visoki broj začeća u travnju $(11,88 \%)$ u župi Desne-Rujnica jasno ukazuje na intenziviranje seksualnih odnosa u vremenu proljetnoga buđenja. ${ }^{26} \mathrm{U}$ ovome se slučaju "buđenje" čak može smatrati donekle zakašnjelim. Možda se time može objasniti pomak prema srpnju, koji je mjesec s najviše začeća (12,28 \%). Srpanjski maksimum u broju začeća donekle čudi s obzirom da tada započinje žetva kultura koje su se nekada mnogo intenzivnije uzgajale u dolini Neretve. Biskupski izvještaji o redovnini iz 18. i 19. stoljeća ukazuju na važnost uzgoja žitarica: pšenice, ječma i sirka te vinove loze. ${ }^{27} \mathrm{No}$, srpanj je ujedno i mjesec s najmanje rođenih (5,61 \%), sukladno najmanjemu broju začeća u listopadu. Također, najveći broj začeća u travnju i srpnju rezultirao je maksimumom rođenih u siječnju i travnju kada su roditelji relativno neopterećeni radovima u polju. Budući da djetetovo rođenje predstavlja veliku obavezu i traži angažman, trebalo bi uzeti u obzir mogućnost planiranja vremena rođenja djeteta. Slične interpretacije u kalkuliranju vremena poroda već su iznesene $\mathrm{u}$ analizi pada broja začeća u jesenskome periodu u Engleskoj. ${ }^{28} \mathrm{U}$ periodu između 1870. i 1880. godine u Desnama se i dalje zadržao visok broj začeća u srpnju, no maksimum je izraženiji tijekom travnja i svibnja. ${ }^{29}$

\section{Broj i tempo poroda ${ }^{30}$}

Prosječno se u braku rađa 3,61 dijete. Ako se iz 69 promatranih parova eliminira šest brakova bez djece, dobivamo gotovo četvero djece $(3,98)$, što je blizu veličine prosječne nuklearne obitelji u susjednome Kominu koja je imala 4,51 dijete. ${ }^{31}$ Vrlo je izvjesno da je prosječan broj djece u braku u župi Desne-Rujnica vjerojatno bio nešto veći, no zbog metoloških ograničenja izostavljeno je mnogo brakova u kojima je ostvaren puni reproduktivni potencijal (npr. ako je brak sklopljen 1820. godine, nije moguće ustanoviti broj djece rođene prije 1825. godine),

\footnotetext{
${ }^{25}$ Bego-Matijević et al., "Tranzicija mortaliteta”, 232-233.

${ }^{26}$ Nenad Vekarić et al., Vrijeme ženidbe i ritam poroda, Dubrovnik i njegova okolica od 17. do 19. stoljeća (Zagreb; Dubrovnik: HAZU, Zavod za povijesne znanosti u Dubrovniku, 2000), 84; Vekarić, VranješŠoljan, "Početak demografske tranzicije u Hrvatskoj", 41.

27 Vidović, Povijest župa doline Neretve, 150-151.

${ }^{28}$ Edward A. Wrigley, Roger S. Schofiled, The population history of England, 1541 - 1871: A reconstruction (Cambridge: Cambridge University Press, 1981): 292.

${ }^{29}$ Bego-Matijević et al. "Tranzicija mortaliteta”, 232-233.

${ }^{30}$ Broj poroda izračunat je za 69 bračnih parova, uglavnom za one za koje je poznata duljina trajanja braka.

31 Šunjić, "Prirodno kretanje stanovništva Komina", 377.
} 
a zbog kratkoće promatranoga razdoblja često nije bio poznat ni konačni broj djece (matica rođenih završava s 1851. godinom). Zbog izostanka stanja duša nije bilo moguće nadopuniti matične knjige kako bi se restituirale obitelji. Osim toga, kao i kod svih analiza koje se koriste matičnim knjigama, javlja se dodatni problem nemogućnosti identificiranja trudnoća koje nisu iznesene do kraja ili su rezultirale rođenjem mrtvorođenoga djeteta, a što je moralo utjecati na razmak između rađanja djece kao i na plodnost žene.

Od brakova koji su registrirani u desanskoj matici vjenčanih šest ih je bilo bez djece. Jedan od tih brakova zbog smrti žene trajao je samo mjesec dana pa mogućnost nije ni postojala. Kratkoća bračnoga suživota vjerojatno je onemogućila stvaranje potomstva kod još dva braka, dok se kod preostala tri zbog dužega bračnog staža može pretpostaviti da je riječ o prirodnome sterilitetu. Najveći broj djece zabilježen je u braku Martina Jelčića i Marije Batinović. Vjenčali su se u studenome 1827. godine, a do veljače 1848. godine zabilježeno je rođenje jedanaestero djece.

\section{Prvo dijete i daljnje širenje obitelji ${ }^{32}$}

Među parovima koji su imali djecu velika većina, gotovo dvije trećine, svoje je prvo dijete začela unutar prve godine bračnoga života. Konkretnije, to znači da je dužina pretporođajnoga intervala kod svih onih parova kojima je sklapanje braka prethodilo začeću djeteta iznosila 19,38 mjeseci (na broju od 121 djeteta), a od sklapanja braka do začeća prvoga djeteta u prosjeku je prošlo nešto više od deset mjeseci. Desetina parova uspjela je začeti dijete već tijekom prvoga mjeseca bračnoga života. Kod gotovo četvrtine parova (23,25\%) od sklapanja braka do začeća prvoga djeteta proteklo je više od godinu dana (u prosjeku dvije godine). Nekim je parovima za začeće prvoga djeteta trebalo i pet do šest godina. Teško je precizirati uzrok. Moguće je da je začeće odgođeno zbog određenih fizioloških problema, ali je isto tako moguće da se u međuvremenu začeće dogodilo, ali je ishod trudnoće bio neuspješan, što onda nije ni zabilježeno u matici niti je to moguće prepoznati na bilo koji način.

Predbračnih začeća je malo - svega tri djeteta koja su rođena do sedam mjeseci nakon sklapanja braka, što čini $2,33 \%$ od broja prvorođene djece. U ovaj broj uključeno je i dijete koje je desanski župnik označio kao izvanbračno jer je rođeno dva mjeseca nakon sklapanja braka roditelja. U posebnu kategoriju spadaju djeca koja su začeta i rođena prije braka i koja su u matičnim knjigama, a i zajednici, označena kao izvanbračna. Prvorođena djeca rođena prije sklapanja braka (izvanbračna djeca) čine tek 3,87 \% ukupnoga broja prvorođene djece.

\footnotetext{
${ }^{32}$ Tempo poroda izračunat je samo za one brakove kod kojih je prvo dijete rođeno u razdoblju između 1825. i 1851. godine. Ukupno je promatrano 129 brakova.
} 
Nakon rođenja prvoga djeteta u pravilu je prošlo mnogo više vremena dok se roditelji ne bi odlučili na daljnje proširenje obitelji (tablica 4). Drugo dijete u prosjeku se rađalo 2,5 godine nakon prvoga. No, ponekad stvari nisu išle prema planu. Dojenčad je bila najugroženija dobna skupina s visokom smrtnošću. ${ }^{33}$ Smrt jednoga djeteta ubrzavala je donošenje odluke o začeću idućega. Primjer su Stanko Jerković i Jurka Mateljak, koji su u 23 godine braka dobili desetero djece. Međuporođajni interval između njihovoga prvog i drugog djeteta bio je skraćen na samo četrnaest mjeseci zbog smrti prvoga djeteta samo četiri mjeseca nakon njegova rođenja. Drugo dijete začeto je mjesec dana nakon bratove smrti, a budući je bio sin, dobio je i bratovo ime (Stipan). To ne vrijedi samo za međuporođajno razdoblje između prvoga i drugoga djeteta nego i za ostale. Dužina svih ostalih međuporođajnih intervala također se kreće između 2,5 i 3 godine.

\section{Izvanbračna djeca}

Izvan braka je rođeno osamnaestero djece (2,43 \%), što je nešto ispod dalmatinskoga prosjeka od oko tri posto, no u skladu je s brojem izvanbračno rođene djece u susjednim neretvanskim mjestima Kominu i Rogotinu u istome periodu. ${ }^{34}$ Iznenađuje što se sedamdesetih godina 19. stoljeća udjel izvanbračne djece u Desnama smanjio na samo $0,77 \% .^{35}$

Roditelji četvero izvanbračno rođene djece u Desnama naknadno su se vjenčali. Dva oca odmah po rođenju priznali su svoju djecu te su ona upisana pod njihovim prezimenima, a do vjenčanja došlo je dva odnosno pet mjeseci nakon poroda.

Sva ostala djeca upisana su pod majčinim prezimenom. Nezakoniti status djece župnik dodatno naglašava uporabom posvojne augmentativne forme majčinoga prezimena koja nastaje dodavanjem sufiksâ -uš i -in/a na osnovu prezimena - na primjer: Jure Vučkušin, to jest Jure Vučković, Jakovica Kalebušina, to jest Jakovica Kaleb ili Iva Ćelušina (Iva Ćelić). Ponekad se umeće i majčino ime - na primjer Manda Jurka Kaleb upisana je kao Manda Jurka Matije Kalebuše. Sufiks - uša vrlo se često koristi u Hercegovini u tvorbi patronimskih nadimaka udanih žena. ${ }^{36}$ Koristi ga i starija populacija u pojedinim neretvanskim mjestima. Do priznanja djeteta u jednome je slučaju došlo naknadno, što je zabilježeno u matici rođenih, a roditelji su se vjenčali godinu dana nakon rođenja djeteta. Priznanje nije išlo "glatko" u slučaju Jure Jerkovića, koji je prema župnikovoj bilješki nakon "uka-

\footnotetext{
${ }^{33}$ Maja Šunjić, "Na dugo pišem jerbo ne mogu se u manje iskazat: uzroci smrti u župi Desne-Rujnica (1825-1861)", Anali Zavoda za povijesne znanosti HAZU u Dubrovniku 51/2 (2013): 469.

${ }_{34}$ Šunjić, "Stanovništvo Rogotina”, 356; Šunjić, "Prirodno kretanje stanovništva Komina”, 376.

${ }^{35}$ Bego-Matijević et al., "Tranzicija mortaliteta”, 213.

${ }^{36}$ Milan Nosić, Prezimena zapadne Hercegovine (Rijeka: Hrvatsko filološko društvo Rijeka, 1998): 141-143.
} 
zivanja" majke Mande Vučković "zatajio" očinstvo nad Ivom Vučković. No, dvije godine nakon rođenja kćeri ipak je došlo do vjenčanja, a djevojčica je naknadno priznata. Njezina prezimenjakinja Marta Vučković imala je dvoje izvanbračne djece prije sklapanja braka s Jurom Marevićem, no nije poznato je li on i otac te djece. I dok se za njezina mlađeg sina možda može pretpostaviti da je otac spomenuti Jure Marević, jer je dječak Jure očito dobio ime prema njemu, za starije dijete vrlo je vjerojatno da Jure Marević nije otac s obzirom da dječaka u matičnoj knjizi umrlih nalazimo pod majčinim prezimenom bez ikakvih naknadnih bilješki. Još su dvije majke djece rođene izvan braka "prokazale" djetetova oca, što je župnik zabilježio, ali uz vlastitu napomenu da im "nije za virovat." Specifičnost Desana u odnosu na neretvanske župe jesu ponavljajući slučajevi izvanbračnih rođenja kod iste majke. Osim Marte Vučković, koja je imala dvoje izvanbračne djece, treba spomenuti i Peru Ćelić, koja je rodila troje djece kao i Matiju Kaleb, koja je u razdoblju od dvanaest godina dobila petero djece bez ikakve napomene o njihovome ocu.

Sve majke izvanbračne djecu bile su "divojke," a samo jedna udovica. Ona je 4,5 godina nakon smrt muža dobila kćer. Prije nje rodila je dvoje djece u braku, a "naslijedila" je i troje djece iz muževa prvog braka.

\section{Dom i obitelj 1802. godine}

Struktura kućanstava i obitelji koje su u njima živjele promatrani su prema stanju duša župe Desne-Rujnica 1802. godine. U cijeloj župi zabilježena su 64 kućanstva. Popis je započeo dana 12. lipnja u Rujnici, nastavljen je 13. lipnja u Desnama i Bagalovićima, a dovršen 14. lipnja u Momićima. Kućanstva su evidentirana prema kućedomaćinima, koji su u 90 \% slučajeva bili muškarci. Domaćinstva se vrlo rijetko vode prema ženama. Uglavnom su to udovice ili neudane žene koje žive same ili s maloljetnim djetetom. Ukućani su popisani prema imenu, ponekad i prezimenu ako ga ne dijele s kućedomaćinom, uz naznaku starosti te njihovoga odnosa prema kućedomaćinu. Redoslijed popisivanja članova obitelji i drugih koji žive u kućanstvu uglavnom ovisi o bliskosti njihove veze s kućedomaćinom. Prednost pri upisu imaju članovi njegove nuklearne obitelji: žena i djeca. Ipak, ponekad je kućedomaćinova majka (u statusu udovice) popisana prije njegove žene. Ako pod istim krovom živi više obitelji, onda će se iza kućedomaćinove obitelji popisati obitelj njegovoga preminulog oca (to jest njegova majka, braća i sestre) odnosno bratova, rođakova ili čak stričeva obitelj. Tek potom slijede nevjenčani članovi obitelji, rođaci i sluge. Muškarci imaju prednost pred ženama, a sinovi pred kćerima. U ovome stanju duša nije zabilježeno podrijetlo rodova. Ponekad je uz imena žena naznačeno ime i prezime njihovoga oca i mjesto podrijetla. Nije moguće odrediti jesu li se sve žene doselile u muževu kuću, no kod složenijih kućanstava u kojima živi više generacija muževe obitelji, to je opravdana pretpostavka. 
U cijeloj župi 1802. godine bilo je 384 stanovnika od čega 191 muškarac i 193 žene. Budući da je popis podijeljen po mjestima, raspolažemo podacima o broju stanovnika u Rujnici, Desnama, Bagalovićima i Momićima. Najbrojnije naselje 1802. godine jest Rujnica s 182 ljudi, od čega 88 muškaraca i 94 žene. Popisano je 27 kućanstava. Slijede Desne sa 110 osoba (52 muškarca i 58 žena) u dvadeset kućanstava. U Bagalovićima je u dvanaest domova živjelo 68 ljudi (36 muškarca i 32 žene). Najmanji naselje su Momići s tek 24 stanovnika (petnaest muškaraca i devet žena).

Ako se promatra župa u cjelini, u strukturi prevladavaju jednostavna kućanstva koja čine nešto manje od polovice svih kućanstava. U takvim domovima uglavnom žive nuklearne obitelji. Najčešće ih čine kućedomaćin, njegova supruga i djeca. Ponekad se kućanstvo vodi prema najstarijemu sinu koji živi zajedno s majkom te braćom i/ili sestrama. U strukturi jednostavnih kućanstava zabilježena je tek jedna zajednica supružnika gdje muž i žena žive sami. Dva jednostavna kućanstva vode se prema ženi - u jednome su živjele majka i kći, a u drugome majka s nezakonitim sinom. Potonje domaćinstvo vjerojatno se ne vodi prema sinu zbog njegova statusa.

Trećina svih kućanstava u župi Desne-Rujnica složena je s višestrukim obiteljima $\mathrm{u}$ strukturi doma. Tu pod istim krovom nalazimo više nuklearnih obitelji koje su nerijetko dodatno proširene još nekim članovima obitelji. Takva složena struktura kućanstva najčešće znači "zajednicu oca i sina," to jest njihovih obitelji. Do nje dolazi tako što sin unutar "očeve obitelji" zasniva vlastitu obitelj. Ako otac umre, kućanstvo se počinje voditi prema sinu, što je vrlo česta situacija u ovoj župi. Tada u njegovoj "staroj" obitelji ("očevoj obitelji bez oca") nalazimo majku te nevjenčanu braću i/ili sestre. Višestruka kućanstva u župi Desne-Rujnica također podrazumijevaju zajednicu braće ili rođaka s vlastitim nuklearnim obiteljima. U dosta kućanstava braća ili rođaci su preminuli, a nakon smrti njihova obitelj ostaje u bratovome ili rođakovom domu. Broj ukućana u složenim kućanstvima kreće se od pet do dvadeset. Najsloženiju situaciju zatičemo u domu harambaše Mate Batinovića staroga 48 godina. Dom je dijelilo čak dvadeset ukućana: Mate i njegova supruga s djecom, njegov brat Marin sa svojom obitelji, obitelj pokojnoga brata Lovre te Matin nećak Martin, majka Manda i sestra, koja se nakon što je postala udovica očigledno vratila u "roditeljski" dom. Na posljednjemu mjestu upisan je Matin nezakoniti sin Mate.

Proširenih kućanstava je malo (10,94 \%). U strukturi takvih kućanstava razaznajemo nuklearnu obitelji s pridruženim članom obitelji, npr. kućedomaćinovom sestrom, bratom ili pak udovicom kućedomaćinova brata. Ponekad pridruženi članovi uopće nisu u srodstvu: zajedno s tročlanom obitelji Šimuna Jeličića živjeli su braća Nikola i Ivan Rakić pokojnoga Ante. Spominju se i sluge: sa Šimunom, nezakonitim Rudanovim sinom i njegovom ženom Jurkom iz Desana živio je Ante Golemac, "njegov momak." Pedesetogodišnja Matija bila je sluškinja 
("momkinja") udovice Andrijane Jurić proširivši njezino izvorno jednočlano kućanstvo na dvije članice.

Na posljednjemu mjestu stanja duša 1802. godine popisana su jednočlana kućanstva. Samački način stanovanja javlja se isključivo kod žena. Nema nijednoga muškarca koji živi sam. U dva slučaja riječ je o udovičkim kućanstvima, a u jednome samačkom-jednočlanom domaćinstvu živjela je neudana žena.

U naselju Rujnica prevladavaju višestruka kućanstva s relativno velikim brojem ukućana od 6,74 osobe u prosjeku, čime je to naselje bliže prosjeku s početka 18 . stoljeća od sedam ukućana ili hercegovačkoj obitelji s prosjekom od sedmero djece. ${ }^{37}$ Moguće je da je kao i kod Komina 1806. godine (s 6,45 ukućana) došlo do privremenoga porasta broja ukućana uvjetovanoga porastom broja stanovnika unutar postojećih struktura kućanstva. ${ }^{38} \mathrm{U}$ naselju Desne broj jednostavnih i višestrukih kućanstava gotovo je izjednačen, a zabilježena su jednočlana i proširena kućanstava. U kućanstvu prosječno živi 5,5 osoba. Gotovo je podjednaka veličina domaćinstva i u Bagalovićima (prosječno 5,66 osoba), s time da tamo prevladavaju jednostavna kućanstva. U Momićima žive isključivo nuklearne obitelji, što znači da su u pitanju isključivo jednostavna kućanstva s 4,8 ukućana u prosjeku. Uglavnom je riječ o mlađemu stanovništvu muškoga spola.

\section{Dobno-spolna struktura stanovništva 1802. godine}

Prosječna starost župljana 1802. godine iznosila je 21,95 godina. Žene u župi bile su u prosjeku četiri godine starije od muškaraca (24,08 naprama 19,8 godina). $\mathrm{U}$ analizi dobne strukture na razini cijele župe (tablica 5, grafikon 2) uočava se velika zastupljenost populacije mlađe od četrnaest godina (43,23\%) jednako kao u parohiji Neretva 1811. godine (41,38 \%) i naselju Komin 1831. godine $(42,41$ \%). ${ }^{39}$ Koeficijent maskuliniteta jest visok (1243) i vjerojatno je povezan s rađanjem većega broja muške nego ženske djece kao opće pojave (tablica 6). ${ }^{40}$ Slični su rezultati dobiveni za druga neretvanska mjesta (tablica 7), s izuzetkom Komina 1796. godine gdje je zabilježeno više djevojčica, no to je lokalna specifičnost koju potvrđuje i lagana prevaga ženske djece u spolnoj strukturi novorođenčadi između 1825. i 1856. godine ${ }^{41}$

U fertilnome kontigentu žene su brojčano nadmašile muškarce, što je karakteristika svih neretvanskih mjesta (tablice 6 i 7), dok na razini cijele Hrvatske u

\footnotetext{
${ }^{37}$ Maja Šunjić, "Stanovništvo parohije Neretva prema anagrafu iz 1811.", Srbsko-dalmatinski magazin 7 (2012): 60-61; Nosić, Prezimena zapadne Hercegovine, 14.

${ }_{38}$ Maja Šunjić, “Stanovništvo Komina u 18. i prvoj polovici 19. stoljeća”, Povijesni prilozi 37 (2009): 331.

39 Šunjić, "Stanovništvo Komina", 332, 342, tablica 5; Šunjić, "Stanovništvo parohije Neretva", 87-88, tablica 4.

${ }^{40}$ Gelo, Demografske promjene u Hrvatskoj, 202.

${ }^{41}$ Šunjić, "Prirodno kretanje stanovništva Komina", 373.
} 
drugoj polovici 19. stoljeća, u fertilnoj i postfertilnoj dobnoj skupini, dolazi do izjednačavanja broja muškaraca i žena. ${ }^{42}$ No, udio starijih muškarca u župi Desne-Rujnica drastično opada te u postfertilnoj populaciji koeficijent maskuliniteta iznosi vrlo niskih 523. Zasigurno je tome pridonio natprosječno velik broj smrti od nesretnih slučajeva i ozljeda zabilježen u ovoj župi. ${ }^{43}$ Niski koeficijenti maskuliniteta također su zabilježeni 1796. godine u Kominu i Rogotinu, 1831. godine u Kominu kao i 1831. godine u Cavtatu i Obodu gdje je muško stanovništvo podjednako izloženo rizicima od nesretnih slučajeva. ${ }^{44} \mathrm{~S}$ druge strane, u parohiji Neretva, čije je stanovništvo uglavnom živjelo u brdskim predjelima, 1811. godine imamo naznake izjednačavanja broja muškaraca i žena (tablica 6) ${ }^{45}$ No, treba napomenuti da se u župi Desne-Rujnica 1802. godine bilježi vrlo malo starijih osoba - udjel osoba starijih od pedeset godina ne prelazi niti $9 \%$. U naseljima Desne, Bagalovići i Momići 1802. godine nema nijedne osobe starije od šezdeset godina. Možda se to može povezati s doseljavanjem mlađega stanovništva na područje ove župe na prijelazu stoljeća i prvim desetljećima 19. stoljeća, koje potvrđuje i analiza rodova i doseljavanja stanovništva. ${ }^{46} \mathrm{U}$ samome naselju Desne iznenađuje izuzetno malen udio staračkoga kontingenta (5,44\%), no zato je tamo zastupljenija fertilna skupina od 15 do 49 godina. U Momićima se uopće ne bilježi nijedna osoba starija od pedeset godina, a udio mlađih od četrnaest godina iznosi gotovo $60 \%$. Iako se to naselje spominje rano u povijesnim izvorima, ova situacija pokazuje da je na prijelazu stoljeća bilo gotovo iznova naseljeno mlađim obiteljima s dominantno muškom populacijom, uglavnom s područja ove župe.

\section{Proces demografske tranzicije u župi Desne-Rujnica kroz usporedbu pokazatelja 1802., 1825. - 1861. (1830. - 1850.) i 1870. - 1880. godine}

Godine 1802. u župi Desne-Rujnica živi vrlo mlado stanovništvo čija prosječna starost jedva doseže 22 godine. Odnos predfertilnoga kontingenta (40 - $60 \%)$ i starijih od pedeset godina $(5,44 \%-10,44 \%)$ ukazuje na predtranzicijski karakter župe u cjelini kao i kod svih naselja. Ekstremni primjer jest naselje Momići gdje nema osobe starije od pedeset godina. Moguće je da je ta situacija uvjetovana migracijama na području župe, ali i prisutnošću rizičnih faktora koji su se ponajprije odrazili na manji broj muškaraca u fertilnome i staračkome kontingentu. U drugoj četvrtini 19. stoljeća, razdoblju koje pokrivaju matične knjige, uočavaju

\footnotetext{
${ }^{42}$ Gelo, Demografske promjene u Hrvatskoj, 202.

${ }^{43}$ Bego-Matijević et al., “Tranzicija mortaliteta”, 217; Šunjić, "Na dugo pišem”, 469.

${ }^{44}$ Niko Kapetanić, Nenad Vekarić, "Stanovništvo Cavtata i Oboda 31. 12. 1830. godine", Anali Zavoda za povijesne znanosti HAZU u Dubrovniku 32 (1994): 120, tablica 2.

${ }^{45}$ Situacija u Rogotinu 1831. godine gdje se bilježi koeficijent maskuliniteta od 1400, koji predstavlja lokalnu specifičnost.

${ }^{46}$ Maja Šunjić, "Povijesna antroponimija i podrijetlo stanovništva župe Desne-Rujnica" (rukopis), predan za objavu u Anale Zavoda za povijesne znanosti HAZU u Dubrovniku 30. siječnja 2017. godine.
} 
se promjene koje se prvenstveno iščitavaju iz povećane dobi udaje žena. Žene u ovoj župi ulaze u brak starije nego u nizu dalmatinskih i neretvanskih mjesta, a taj pokazatelj dodatno potvrđuje vrlo malen broj žena koje su se vjenčale prije navršene 20. godine. Neobično je što će između 1870. i 1880. godine dob udaje žena ostati gotovo nepromijenjena, a proces demografske tranzicije ponajprije će se očitovati u povećanoj ženidbenoj dobi muškaraca i smanjenju broja muškaraca koji su u brak ušli prije 20. godine života. ${ }^{47}$ Taj trend "regresije" kod žena možda se još jasnije iščitava u gotovo dvostruko većemu broju djevojaka koje ulaze u brak prije navršene 20. godine života između 1870. i 1880. godine (od 8,95 \% 1825. - 1857. godine na $17,10 \% 1870$. - 1880. godine). ${ }^{48}$ Moguće je da ta pojava ima veze sa svojevrsnom "tradicionalizacijom" prema kraju 19. stoljeća na koju upućuju i drugi pokazatelji. Već je napomenuto da u sezonskome kretanju vjenčanja tijekom adventa dolazi do pada u broju vjenčanja. No, udjel prosinačkih vjenčanja u župi Desne-Rujnica s 4,8 \%, u razdoblju od 1825. do 1857. godine smanjio se na samo $1,90 \%$ između 1870 . i 1880. godine, što podrazumijeva veću "stegu" u poštovanju zabrana. Udjel izvanbračne djece od početnih 2,43 \% prema sedamdestim godinama 19. stoljeća smanjio se na "puritanskih" 0,77 \%. Broj udovica koje ponovno ulaze u brak prepolovio se 1870-ih, dok se kod udovaca odnos prema ponovnome braku nije mnogo promijenio ako je suditi prema podjednakome broju u oba promatrana razdoblja. ${ }^{49}$

Kako bi se ovaj nagovještaj tranzicije vezan uz dob ženine udaje u razdoblju od 1825. do 1857. godine podrobnije ispitao, dodatno su ispitani još neki pokazatelji prirodnoga kretanja stanovništva, koji uključuju analizu stope nataliteta, mortaliteta, prirodnoga prirasta i migracijskoga salda u periodu između 1830. i 1850. godine na temelju broja stanovnika popisanih 1830. i 1854. godine. ${ }^{50}$ Godine 1830. u Desnama je živjelo 636 stanovnika, a za 1850. godine izračun daje 917,6 stanovnika, što znači porast od 44,28 \%. S godišnjim prosjekom od 1,69 migracijski saldo je pozitivan, što potvrđuju i povijesna istraživanja, a porastu stanovništva zasigurno je pridonijela i prosječna stopa prirodnoga prirasta od 16,76 \%o.

Prosječna stopa nataliteta od 36,77 \%o nešto je viša nego u Dalmaciji u istome periodu (32,23\%o), a idućih godina smanjuje se laganim ritmom prema 35,06 \%o koliko je u Desnama zabilježeno 70 -ih godina 19 . stoljeća. ${ }^{51}$ Prosječna stopa

\footnotetext{
${ }^{47}$ Bego-Matijević et al., “Tranzicija mortaliteta”, 215.

${ }^{48}$ Isto.

${ }^{49} \mathrm{Za}$ sve navedene pokazatelje između 1870. i1880. godine vidjeti: Bego-Matijević et al., "Tranzicija mortaliteta", 211, 213, 215 i Tablica 6.

${ }^{50}$ Mithad Kozličić, Ante Bralić, Stanovništvo kraljevine Dalmacije prema službenim izračunima i popisima 1828.-1857. godine (Zadar: Sveučilište u Zadru, 2012), 67, 76, 205, 216. Budući da matična knjiga rođenih završava u rujnu 1851. godine, kao posljednja godina uzeta je 1850. godina za koju je izračun broja stanovnika napravljen prema popisima iz 1830. godine (636 stanovnika) i 1854. godine (974 stanovnika). Ostali podaci temelje se na upisima iz matičnih knjiga.

${ }^{51}$ Gelo, Demografske promjene u Hrvatskoj, 276, Napomena: prosjek za razdoblje od 1830. do 1850. godine izračunat je na temelju podataka u tablici 9.1.2; Bego-Matijević et al., "Tranzicija mortaliteta”, 204.
} 
mortaliteta od 20,01 \%o od 1830. do 1850. godine niža je od prosjeka Dalmacije $\mathrm{u}$ istome periodu $(24,81 \%)$, a trend smanjenja smrtnosti nastavit će se prema razdoblju između 1870 . i 1880 . godine do $16,90 \% 0 .{ }^{52}$ Stopa mortaliteta, sukladno očekivanjima, opada brže nego stopa nataliteta.

Analiza dobno-spolne strukture stanovništva župe Desne-Rujnica između 1825. i 1861 . te 1870 . i 1880 . godine pokazuje gotovo podjednaku smrtnost dojenčadi (16,72 \% i 16,96 \%)..$^{53}$ Ako u obzir uzmemo i malenu djecu, od 1825. do 1861. godine taj je udio čak i manji (ukupno 28,93 \%) nego 70-ih godina 19. stoljeća $(37,39 \%)$. Neuobičajeno malena smrtnost dobne skupine $0-4$ godine dovela je u pitanje ažurnost upisa dojenčadi u matične knjige. ${ }^{54}$ Činjenica da je od 1825. do 1861. godine smrtnost te dobne skupine bila još manja možda pobuđuje dodatne sumnje, no razlika se zapravo odnosi na dobnu skupinu $1-4$ godine gdje se očekuje veća pedantnost upisa. Usporedba upisa u maticama rođenih i umrlih u razdoblju od 1825. do 1851. godine pokazuje da se možda može sumnjati u upise mrtvorođenčadi i perinatalne smrtnosti, moguće i neonatalne smrtnosti, dok je upis smrtnosti dojenčadi i djece ažuran. K tome, u župi se nakon 1863. godine promijenio župnik pa zapravo imamo dva sasvim različita autora izvora. Oba objašnjenja nisu ništa više od indicije za pouzdanost upisa, no neosporna je činjenica da se isti pokazatelj javlja u dva neovisno analizirana perioda pa ga svakako treba uzeti u obzir. U oba promatrana perioda u Desnama se bilježi nešto veća smrtnost fertilnoga kontingenta, a neobično je što se udio osoba starijih od sedamdeset godina smanjuje prema kraju stoljeća (s 11,2 \% od 1825. do 1861. godine na $7,39 \%$ od 1870 . do 1880 . godine).$^{55}$ Odnos dječjega kontingenta $(0-4)$ i onih starijih od 70 iznosi 2,58:1.

\section{Zaključak}

Svi navedeni pokazatelji govore da je proces demografske tranzicije u župi DesneRujnica u drugoj četvrtini 19. stoljeća već započeo. Rezultati za ovaj period uglavnom su konzistentni s onima dobivenima za razdoblje od 1870. do 1880. godine i potvrđuju da je tranzicija mortaliteta započela smanjenjem smrtnosti dojenčadi i malene djece. Određene nelogičnosti poput povećanja smrtnosti dobne skupine $1-4$ godine i smanjenja broja starijih od sedamdeset godina između razdobljâ 1825. - 1861. i 1870. - 1880. godine nije moguće objasniti, dok druge pokazatelje poput stagnacije dobi udaje žena i većega broja žena koje se udaju prije navršene

\footnotetext{
${ }^{52}$ Bego-Matijević et al. "Tranzicija mortaliteta”, 204.

${ }^{53}$ Bego-Matijević et al., "Tranzicija mortaliteta", 208-209, tablica 5, 216-217; Šunjić, "Na dugo pišem”, 495.

${ }^{54}$ Vekarić, Vranješ-Šoljan, "Početak demografske tranzicije u Hrvatskoj", 33, 36.

${ }^{55}$ Bego-Matijević et al., “Tranzicija mortaliteta”, 208-209, tablica 5, 216-217; Šunjić, "Na dugo pišem”, 495.
} 
20. godine života vjerojatno treba vezati uz trend tradicionalizacije društvenoga okružja.

Ako promotrimo tri osnovne tematske sastavnice ovoga rada: vjenčanje, porod i dom, vidimo da su one u 19. stoljeću u najvećemu broju slučajeva povezane. Sve počinje s vjenčanjem kao preduvjetom za zajednički život u vlastitomu domu ili priključivanjem mladoga para mladoženjinu domu u kojemu će dobiti potomstvo. Stanovnici župe Desne-Rujnica najčešće se vjenčaju u studenome, a "sezona vjenčanja" proteže se na cijelu jesen, počevši od rujna te se - uz prekid tijekom adventa - nastavlja u siječnju i veljači. U neretvanskome kontekstu s izrazitim zimskim maksimumom, ova župa predstavlja izuzetak koji dodatno potvrđuju istraživanja za period od 1870. do 1880. godine.

Iako najveći broj kućanstava ima jednostavnu strukturu, zbog brojnosti višestrukih obitelji, koje mogu doseći i do dvadeset ukućana, najviše ljudi zapravo živi u složenim kućanstvima koja uglavnom čine muževi srodnici. Nakon vjenčanja bračni parovi nastojali su čim prije dobiti prvo dijete, dok su kod daljnjega proširenja obitelji radili veće razmake. Datumi poroda na temelju kojih je izračunato sezonsko kretanje začeća pokazuju da vrijeme začeća, barem na godišnjoj/ sezonskoj razini, ovisi i o vanjskim faktorima. Najočigledniji dokaz za to jest smanjenje broja začete djece tijekom korizme i adventa. No, daleko najmanji broj začeća bilježi se u listopadu, a "zastoj začeća" proteže se kroz cijelu jesen. To je donekle povezano s jesenskim radovima u vinogradima i maslinicima. No, ne bi trebalo izgubiti iz vida ni činjenicu da su se u 18. i 19. stoljeću na ovome području najintenzivnije uzgajale žitarice. Vrijeme njihove žetve jest srpanj i početak kolovoza, što se preklapa s vremenom jednoga od maksimuma u broju začetih. Stoga se postavlja pitanje kako najveći radovi u polju mogu rezultirati najmanjim i najvećim brojem začeća. Ako se stvari promatraju na elementarnoj razini, začeće djeteta traži mnogo manji angažman od rođenja. Žena koja je rodila morala je neko vrijeme biti pošteđena rada u polju, što je jedan par ruku manje u vrijeme kada su najpotrebnije. Srpanj je ujedno i mjesec s najmanjim brojem rođenih, što sugerira svojevrsnu kalkulaciju vremena rođenja - smanjen broj začeća u listopadu znači manje poroda u srpnju. Osim u srpnju maksimum začeća javlja se još i u travnju. Pojava većega broja začeća u proljeće uobičajena je pojava u nizu istraživanih područja, s time da se ovdje javlja nešto kasnije. U travnju se, uz siječanj, također rađa najviše djece. Oba mjeseca donose predah od većih radova u polju i roditelji su mogli biti posvećeniji novorođenčadi. 


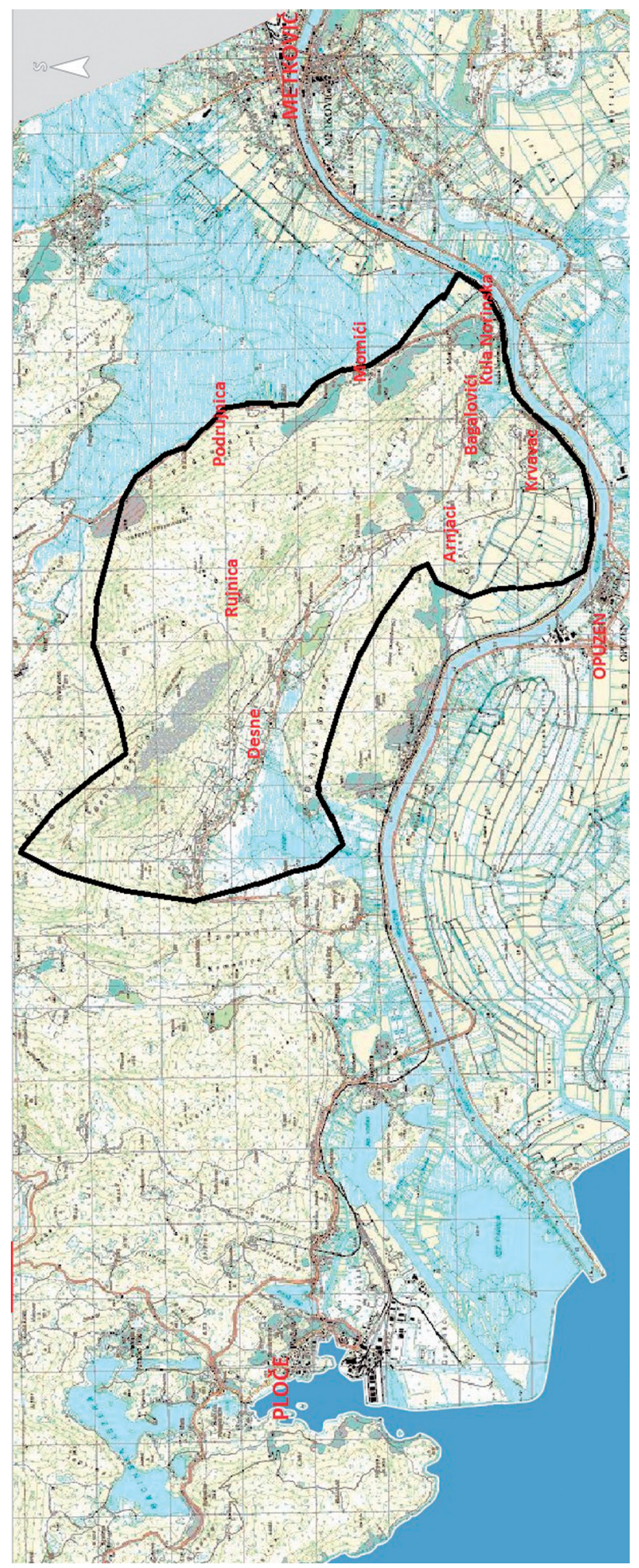




\section{PRILOZI}

Grafikon 1: Sezonsko kretanje vjenčanja, začeća i rođenja

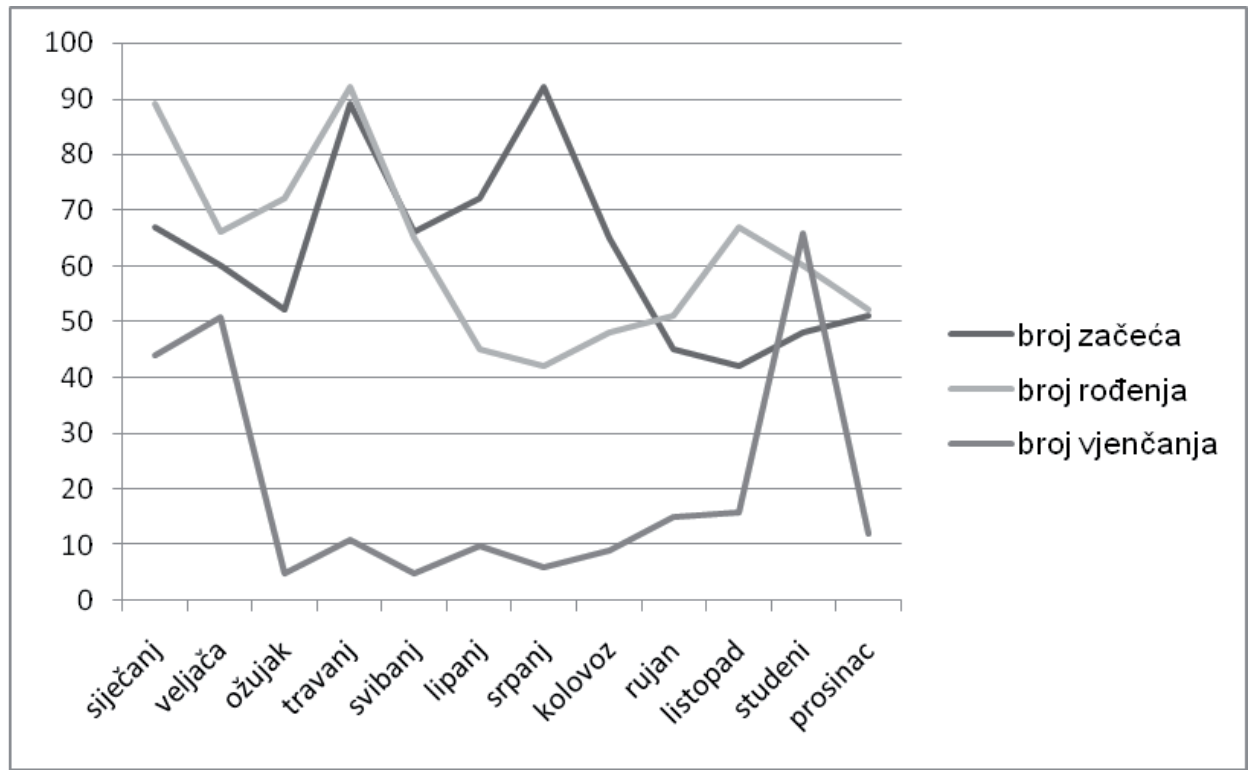

Izvor: DAZd, Zbirka matičnih knjiga, MKR 1825.-1830., MKR 1830.-1851., MKV 1825.1831. i MKV 1831.- 1857.

Grafikon 2: Udio dobnih skupina u župi Desne-Rujnica 1802. godine

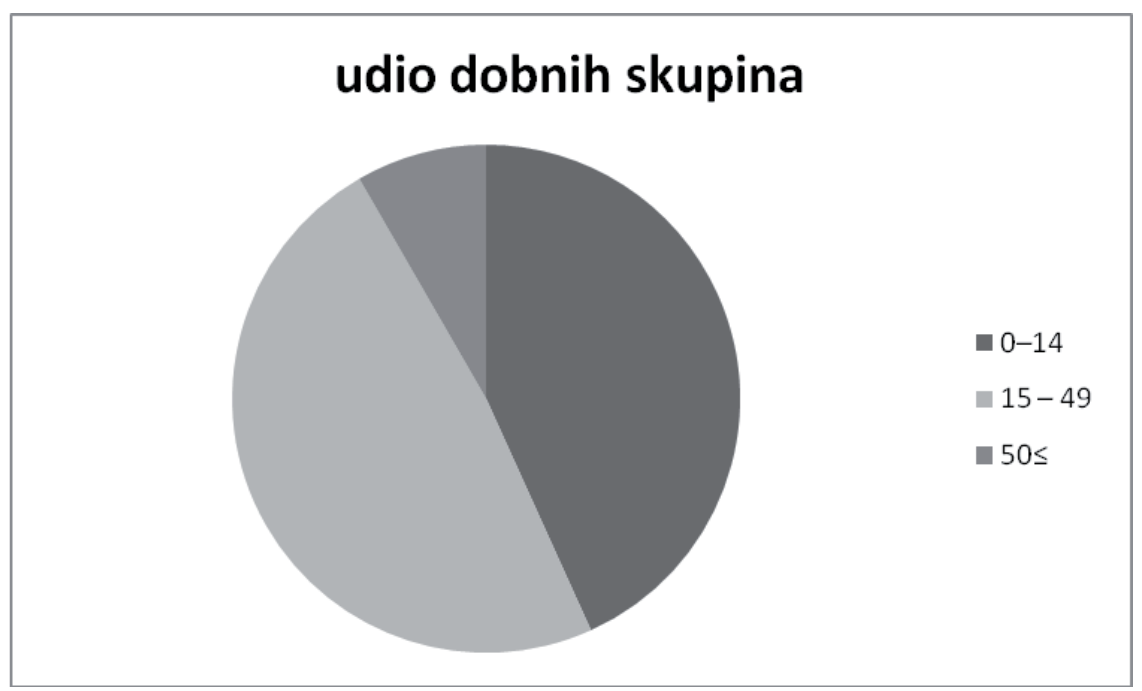

Izvor: Nadbiskupski arhiv u Splitu, M 113, Stanje duša župe Desne-Rujnica 1802. godine (bez paginacije) 
Tablica 1: Sezonsko kretanje vjenčanja, začeća i rođenja

\begin{tabular}{|l|c|c|c|}
\hline \multicolumn{1}{|c|}{ Mjesec } & Vjenčanja (\%) & Začeća (\%) & Rođenja (\%) \\
\hline Siječanj & 17,6 & 8,95 & 11,88 \\
\hline Veljača & 20,4 & 8,01 & 8,81 \\
\hline Ožujak & 2,00 & 6,94 & 9,61 \\
\hline Travanj & 4,40 & 11,88 & 12,28 \\
\hline Svibanj & 2,00 & 8,81 & 8,68 \\
\hline Lipanj & 4,00 & 9,61 & 6,01 \\
\hline Srpanj & 2,40 & 12,28 & 5,61 \\
\hline Kolovoz & 3,60 & 8,68 & 6,41 \\
\hline Rujan & 6,00 & 6,01 & 6,81 \\
\hline Listopad & 6,40 & 5,61 & 8,95 \\
\hline Studeni & 26,40 & 6,41 & 8,01 \\
\hline Prosinac & 4,80 & 6,81 & 6,94 \\
\hline Ukupno (\%) & 100 & 100 & 100 \\
\hline Ukupno (broj) & 250 & 749 & 749 \\
\hline
\end{tabular}

Izvor: DAZd, Zbirka matičnih knjiga, MKR 1825. - 1830., MKR 1830. - 1851., MKV 1825. - 1831. i MKV 1831.- 1857.

Tablica 2: Izbor dana vjenčanja (1825. - 1857.)

\begin{tabular}{|l|c|}
\hline Dan & Udjel (\%) \\
\hline Ponedjeljak & 73,6 \\
\hline Utorak & 6,00 \\
\hline Srijeda & 2,00 \\
\hline Četvrtak & 1,60 \\
\hline Petak & 2,80 \\
\hline Subota & 2,00 \\
\hline Nedjelja & 12,00 \\
\hline Ukupno (\%) & 100 \\
\hline Ukupno (broj) & 250 \\
\hline
\end{tabular}

Izvor: DAZd, Zbirka matičnih knjiga, MKV 1825. - 1831. i MKV 1831 .- 1857. 
Tablica 3: Dob pri sklapanju braka (1825. - 1857.)

\begin{tabular}{|l|c|c|c|c|c|c|}
\hline \multirow{2}{*}{} & \multicolumn{2}{|l|}{ Svi brakovi (\%) } & \multicolumn{2}{l|}{ Ponovljeni brakovi (\%) } & \multicolumn{2}{l|}{$\begin{array}{c}\text { Samo prvi brakovi obaju } \\
\text { supružnika (\%) }\end{array}$} \\
\cline { 2 - 7 } & $\mathrm{M}$ & $\check{Z}$ & $\mathrm{M}$ & $\check{Z}$ & $\mathrm{M}$ & $\check{Z}$ \\
\hline do 19 & 4,43 & 7,26 & 0 & 0 & 5,47 & 8,95 \\
\hline $20-24$ & 28,63 & 39,11 & 6,38 & 25,53 & 33,83 & 42,29 \\
\hline $25-29$ & 34,68 & 41,53 & 19,15 & 38,3 & 38,31 & 42,29 \\
\hline $30-34$ & 17,34 & 7,26 & 12,77 & 17,02 & 18,41 & 4,98 \\
\hline $35-39$ & 8,87 & 3,63 & 31,91 & 12,77 & 3,48 & 1,49 \\
\hline $40-44$ & 2,82 & 1,21 & 12,77 & 6,38 & 0,5 & 0 \\
\hline $45-49$ & 0,4 & 0 & 2,12 & 0 & 0 & 0 \\
\hline $50-54$ & 2,02 & 0 & 10,64 & 0 & 0 & 0 \\
\hline $55-59$ & 0,81 & 0 & 4,26 & 0 & 0 & 0 \\
\hline Ukupno & 100 & 100 & 100 & 100 & 100 & 100 \\
\hline Ukupno (broj) & 248 & 248 & 47 & 47 & 201 & 201 \\
\hline
\end{tabular}

Izvor: DAZd, Zbirka matičnih knjiga, MKV 1825. - 1831. i MKV 1831. - 1857.

Tablica 4: Tempo međuporođajnih intervala (1825. - 1851.)

\begin{tabular}{|l|c|c|}
\hline Vremenski razmak između rođenja: & $\begin{array}{c}\text { Prosječni interval } \\
\text { (u mjesecima) }\end{array}$ & $\begin{array}{c}\text { Veličina uzorka } \\
\text { (broj brakova) }\end{array}$ \\
\hline Prvog i drugog djeteta & 30,84 & 106 \\
\hline Drugog i trećeg djeteta & 33,9 & 82 \\
\hline Trećeg i četvrtog djeteta & 36,47 & 56 \\
\hline Četvrtog i petog djeteta & 35,42 & 43 \\
\hline Petog i šestog djeteta & 37,81 & 27 \\
\hline Šestog i sedmog djeteta & 34,45 & 11 \\
\hline Sedmog i osmog djeteta & 28 & 5 \\
\hline Osmog i devetog djeteta & 25,66 & 3 \\
\hline Devetog i desetog djeteta & 30,5 & 2 \\
\hline Desetog i jedanaestog djeteta & 35 & 1 \\
\hline
\end{tabular}

Izvor: DAZd, Zbirka matičnih knjiga, MKR 1825.-1830., MKR 1830.-1851.

Tablica 5: Udjel dobnih skupina prema naseljima i na razini župe Desne-Rujnica 1802. godine

\begin{tabular}{|l|c|c|c|c|}
\hline \multirow{2}{*}{} & \multicolumn{3}{|c|}{ Dobna skupina (\%) } & \multirow{2}{*}{ Ukupan broj } \\
\cline { 2 - 4 } & $0-14$ & $15-49$ & $50 \leq$ & \\
\hline Rujnica & 40,66 & 48,90 & 10,44 & 182 \\
\hline Desne & 39,99 & 54,57 & 5,44 & 110 \\
\hline Bagalovići & 49,98 & 39,73 & 10,29 & 68 \\
\hline Momići & 58,32 & 41,68 & - & 24 \\
\hline Župa Desne-Rujnica & 43,23 & 48,43 & 8,33 & 384 \\
\hline
\end{tabular}

Izvor: Nadbiskupski arhiv u Splitu, M 113, Stanje duša župe Desne-Rujnica 1802. godine (bez paginacije) 
Tablica 6: Koeficijenti maskuliniteta $(\mathrm{Km})$ i feminiteta $(\mathrm{Kf})$ prema dobnim skupinama užupi Desne-Rujnica 1802. godine

\begin{tabular}{|l|c|c|c|c|}
\hline \multirow{2}{*}{ Dobna skupina } & \multicolumn{2}{|c|}{ Muškarci } & \multicolumn{2}{c|}{ Žene } \\
\cline { 2 - 5 } & Broj & Km & Broj & Kf \\
\hline $0-14$ & 92 & 1243 & 74 & 804 \\
\hline $15-49$ & 88 & 897 & 98 & 1113 \\
\hline $50 \leq$ & 11 & 523 & 21 & 1909 \\
\hline Ukupno & 191 & 989 & 193 & 1010 \\
\hline
\end{tabular}

Izvor: Nadbiskupski arhiv u Splitu, M 113, Stanje duša župe Desne-Rujnica 1802. godine (bez paginacije)

Tablica 7: Usporedni prikaz koeficijenata maskuliniteta $(\mathrm{Km})$ i feminiteta $(\mathrm{Kf})$ prema dobnim skupinama na području donje Neretve

\begin{tabular}{|l|c|c|c|c|c|c|}
\hline \multirow{2}{*}{ Mjesto/župa/parohija } & \multicolumn{6}{|c|}{ Dobna skupina } \\
\cline { 2 - 7 } & \multicolumn{2}{|c|}{$0-14$} & \multicolumn{2}{c|}{$15-49$} & \multicolumn{2}{c|}{$50 \leq$} \\
\cline { 2 - 7 } & $\mathrm{Km}$ & $\mathrm{Kf}$ & $\mathrm{Km}$ & $\mathrm{Kf}$ & $\mathrm{Km}$ & Kf \\
\hline Župa Desne-Rujnica 1802. & 1243 & 804 & 897 & 1113 & 523 & 1909 \\
\hline Parohija Neretva 1811. & 1170 & 854 & 886 & 1128 & 990 & 1150 \\
\hline Komin 1796. & 540 & 1850 & 971 & 1029 & 500 & 2000 \\
\hline Rogotin 1796. & 1133 & 882 & 875 & 1142 & 666 & 1500 \\
\hline Komin 1831. & 1120 & 892 & 821 & 1216 & 789 & 1266 \\
\hline Rogotin 1831. & 1560 & 640 & 783 & 1275 & 1400 & 714 \\
\hline
\end{tabular}

Izvori i literatura: Nadbiskupski arhiv u Splitu, M 113, Stanje duša župe Desne-Rujnica 1802. godine (bez paginacije)

Šunjić, “Stanovništvo parohije Neretva”, 88, tablica 4 (Stanje duša parohije Neretva 1811. godine)

Šunjić, “Stanovništvo Rogotina”, 381, 384, tablice 12 i 13 i Šunjić, “Stanovništvo Komina”, 342, tablice 4 i 5 (Stanja duša župe Komin-Rogotin 1796. i 1831. godine) 


\section{Izvori}

Hrvatska - Državni arhiv u Zadru - Zbirka matičnih knjiga - Matična knjiga rođenih 1825-1830, inv.br. 169

Hrvatska - Državni arhiv u Zadru - Zbirka matičnih knjiga - Matična knjiga rođenih 1830-1851 (dalje: MKR 1830-1851), inv. br. 170.

Hrvatska - Državni arhiv u Zadru - Zbirka matičnih knjiga - Matična knjiga vjenčanih (dalje: MKV 1825-1831), inv. br. 171.

Hrvatska - Državni arhiv u Zadru - Zbirka matičnih knjiga - Matična knjiga vjenčanih 1831-1857 (dalje: MKV 1831-1857), inv. br. 172.

Hrvatska - Državni arhiv u Zadru - Zbirka matičnih knjiga - Matična knjiga umrlih 1825-1861 (dalje: MKU 1825-1861, inv. br. 173.

Hrvatska - Nadbiskupski arhiv u Splitu - M 113 - Status animarum župe DesneRujnica 1802. godine.

Hrvatska - Nadbiskupski arhiv u Splitu - M 67 - Status animarum sela Vid, Borovci i Rujnica 1744. godine.

Despot, Žarko (pripremio). Codex Baptismorum Descriptoru' Post Ordinationem Concilii Tridentini (Prijepis matične knjige oznake SK 198 iz Arhiva franjevačkoga samostana u Zaostrogu - neobjavljeno.)

\section{Objavljeni izvori i literatura}

Andreis, Mladen. "Povijesna demografija Velog Drvenika, Malog Drvenika i Vinišća do god. 1900.” Radovi Zavoda za povijesne znanosti HAZU u Zadru 40 (1998): 227-301.

Benedict, Philip. "The Huguenot Population of France, 1600-1685: The Demographic Fate and Customs of a Religious Minority". Transactions of the American Philosophical Society 81 (1991, reprinted 1994), br. 5: I-IX, 1-164.

Bego-Matijević, Inge; Dugandžić, Žarko; Akrap, Anđelko. “Tranzicija mortaliteta: Stanovništvo Desne na Neretvi (1870-1880)”. Anali Zavoda za povijesne znanosti HAZU u Dubrovniku 47 (2009): 195-218.

Dugandžić, Žarko. “Stanovništvo općine Metković 1850.-1918.. Doktorska disertacija, Sveučilište u Zagrebu, 2011.

Dugandžić, Žarko. “Demografske značajke župe Baćina od 1870. do 1880. godine”. Hum - časopis Filozofskog fakulteta Sveučilišta u Mostaru 10 (2013): 420-451.

Dugandžić, Žarko. "Na pragu demografske tranzicije: stanovništvo župe Opuzen (1870.-1880.)”. Mostariensia 19 (2015): 93-115.

Gelo, Jakov. Demografske promjene u Hrvatskoj: od 1780. do 1981. godine. Zagreb: Globus, 1987. 
Jerković, Radovan. Gabela (Prilog povijesti Donje Neretve). Sarajevo: „Napredak“ - Hrvatski narodni kalendar, 1939.

Kapetanić, Niko; Vekarić Nenad. "Stanovništvo Cavtata i Oboda 31. 12. 1830. godine”. Anali Zavoda za povijesne znanosti HAZU u Dubrovniku 32 (1994): 117142.

Kozličić, Mithad; Bralić, Ante. Stanovništvo kraljevine Dalmacije prema službenim izračunima i popisima 1828.-1857. godine. Zadar: Sveučilište u Zadru, 2012.

Nosić, Milan. Prezimena zapadne Hercegovine. Rijeka: Hrvatsko filološko društvo Rijeka, 1998.

Petrović, Đurđica. Dubrovačko oružje u XIV. veku, knj. 5. Beograd: Posebna izdanja/Vojni muzej u Beogradu, 1976.

Rihtman-Auguštin, Dunja. Knjiga o Božiću, Etnološki prikaz Božića i božičnih običaja u hrvatskoj narodnoj kulturi. Zagreb: August Cesarec; Mosta; Institut za etnologiju i folkloristiku, 1992.

Sarti, Raffaella. Živjeti u kući. Stanovanje, prehrana i odijevanje u novovjekovnoj Europi (1500.-1800.), prev. Ana Badurina. Zagreb: Ibis grafika, 2006.

Šunjić, Maja. "Stanovništvo Rogotina na kraju 18. i u prvoj polovici 19. stoljeća na temelju matičnih knjiga i stanja duša". Anali Zavoda za povijesne znanosti HAZU u Dubrovniku 45 (2007): 347-389.

Šunjić, Maja. "Prirodno kretanje stanovništva Komina na kraju 18. i prvoj polovici 19. stoljeća". Anali Zavoda za povijesne znanosti HAZU u Dubrovniku 50 (2012): 365-384.

Šunjić, Maja. "Stanovništvo parohije Neretva prema anagrafu iz 1811.” Srbskodalmatinski magazin 7 (2012): 52-102.

Šunjić, Maja. "Na dugo pišem jerbo ne mogu se u manje iskazat: uzroci smrti u župi Desne-Rujnica (1825-1861)". Anali Zavoda za povijesne znanosti HAZU u Dubrovniku 51 (2013), br. 2: 461-499.

Šunjić, Maja. "Povijesna antroponimija i podrijetlo stanovništva župe DesneRujnica" (rukopis), predan za objavu u Anale Zavoda za povijesne znanosti HAZU u Dubrovniku 30. 1.2017. (neobjavljeno).

Vekarić, Nenad; Benyovsky, Irena; Buklijaš, Tatjana; Levak, Maurizio; Lučić, Nikša; Mogorović, Marija; Primorac, Jakša. Vrijeme ženidbe i ritam poroda, Dubrovnik i njegova okolica od 17. do 19. stoljeća. Zagreb - Dubrovnik: HAZU Zavod za povijesne znanosti u Dubrovniku, 2000.

Vekarić, Nenad; Vranješ-Šoljan, Božena. "Početak demografske tranzicije u Hrvatskoj”. Anali Zavoda za povijesne znanosti HAZU u Dubrovniku 47 (2009): 9-62 Vidović, Mile. Povijest župa doline Neretve. Metković: Ogranak Matice hrvatske u Metkoviću, 2011. 
Wrigley, Edward A.; Schofiled, Roger S. The population history of England, 1541

- 1871: A reconstruction. Cambridge: Cambridge University Press, 1981. 


\title{
Population of the Desne-Rujnica Parish during the First Half of the $19^{\text {th }}$ Century
}

\author{
Maja Šunjić \\ Obala 1 br. 23 \\ 20270 Vela Luka \\ Croatia \\ E-mail: maja.sunjic11@gmail.com
}

\section{Summary}

Based on the registry books of the Desne-Rujnica parish, this article analyses the various components of natural demographic processes, as well as issues related to marriages and births (seasonal variations in weddings, conceptions, and births, second marriages, extramarital children, and so on) during the second quarter of the $19^{\text {th }}$ century. In the Desne-Rujnica parish, most weddings took place in November, with the "wedding season" spanning over the entire autumn, from September to January and February, with the exception of the Advent period. The time between marriage and the conception of the first child was usually around ten months, whereby this period became longer with the following children. Regularities can be observed on a yearly basis. The fewest conceptions are registered in October, with a "break" that lasted throughout the autumn months. This pattern of the maximum or minimum number of conceptions and births reflects a sort of calculations concerning the child's birth date.

A link between weddings and family (births) are households, which have been analysed on the basis of the population size and structure in the Desne-Rujnica parish in 1802. The relationship between the number of children and elderly indicates the pre-transitional character of the parish as a whole, as well as its individual settlements. All analysed parameters show that the process of demographic transition had already started by the second quarter of the $19^{\text {th }}$ century, its features being very similar to those in the period from 1870-1880. A series of changes observed between the second quarter of the $19^{\text {th }}$ century and the 1870 s (the age of married women, a diminished number of weddings during the Advent period, the number of extramarital children and widows entering a second marriage) indicates a sort of "traditionalization" of this area towards the end of the century.

Keywords: Desne, Rujnica, Neretva, weddings, births, demographic transition, $19^{\text {th }}$ century 